\title{
Stabilization and Economic Reform in Russia
}

ONLY A HANDFUL of events in this century are as important as the creation and eventual collapse of the Soviet Union. That the Soviet Union disappeared with minimal loss of life is as extraordinary as its demise. While the political changes have been exceptional, the pace and extent of economic change have been sweeping, too. Less than four months after the Soviet Union was dissolved, Russia had decisively liberalized most prices and was on the road to macroeconomic stabilization and convertibility of the ruble. The budget deficit has been cut from 20 to less than 10 percent of gross domestic product (GDP). The inflation rate has been declining, after a price level adjustment. At the end of April 1992, Russia joined the International Monetary Fund (IMF) and the World Bank. Well before the end of the year, Russia will be receiving IMF financial support to implement a stabilization and reform process that probably will include converting the ruble at a fixed rate.

Rapid stabilization in Russia-along with price and trade liberalization and currency convertibility - will be an extraordinary accomplishment, if it is achieved. ${ }^{1}$ But both the emerging record of Eastern Europe and the early evidence from Russia suggest that the more challenging and ultimately more important difficulties lie elsewhere: in privatiza-

I am grateful for comments by Michael Bruno, William Nordhaus, and Lawrence Summers; research assistance from Ruth Judson; and research support from the National Science Foundation.

1. Stabilization from the current situation should be judged to be reasonably successful if the inflation rate is reduced to less than 30 to 40 percent a year; the budget deficit is sustainable with non-inflationary financing, implying a level of 4 to 5 percent of GDP or less; and the current account deficit is covered by orderly external financing. 
tion; in the distribution sector; in financial, fiscal, and agricultural reform-in short, in the structural reform of the economy.

The cumulative decline in output in the Soviet Union in 1990 and 1991 was similar to that experienced in the major Eastern European countries, as shown in table 1. Supply disruptions in the oil sector, the breakdown of the state order system, and severe disruptions in inter-republican trade exacted their toll on economic performance. For the former Soviet Union (FSU), as for the Eastern European countries, exports and imports declined sharply in 1991. However, in the FSU, much of the decline-one-third of exports-resulted from domestic supply disruptions, particularly in the oil industry.

Russia embarked on its reform program at the end of 1991 facing an impressive array of problems. First, as already noted, output had fallen by nearly 20 percent. Moreover, the inflationary overhang produced a 350 to 400 percent increase in prices within a month after prices were liberalized in January 1991. Second, the Group of Seven industrialized democracies (G-7) was intent on getting the 15 republics to recognize their "joint and several" responsibility for the Soviet Union's $\$ 80$ billion external debt and seemingly uninterested in providing direct financial support for economic reform.

Third, the incoming policymakers had to assemble a civil service and administration from the remnants of the Soviet system at the same time as they were planning their reforms. (In this respect, the Russian government, based in Moscow, was in much better shape than the other republics.) The breakdown of authority in the Soviet Union also has extended to authority within Russia, with its sixteen autonomous regions and subregional units reaching for greater independence-the more so the greater their resource riches. Even today, reports suggest that the reach of the central Russian administration is limited and that regional and local officials freely ignore instructions from central authorities.

Fourth, trading and currency relations among the republics are in a state of flux. The republics of the new Commonwealth have agreed in principle to continue using the ruble for two years, but there is no doubt that Ukraine is already implicitly introducing a separate currency through its coupon system and little doubt that it will explicitly introduce a separate currency later this year. In addition, the entire range of political issues following the breakup of the Soviet Union, including the dis- 
Table 1. The Economic Performance of Eastern Europe and the Soviet Union, 1990-91 ${ }^{\mathrm{a}}$ Percent, except where indicated ${ }^{\mathrm{b}}$

\begin{tabular}{lccccc}
\hline Macroeconomic indicator & CSFR $^{c}$ & Hungary & Poland & Romania & $\begin{array}{r}\text { Soviet } \\
\text { Union }\end{array}$ \\
\hline $\begin{array}{l}\text { Output growth } \\
1990\end{array}$ & -1 & -4 & -12 & -7 & -4 \\
$1991^{\mathrm{d}}$ & -16 & -8 & -8 & -12 & -13 \\
& $(-9)$ & $(-8)$ & $(-4)$ & $(-10)$ & $(-4)$ \\
Inflation & & & & & \\
$\quad 1990$ & 54 & 33 & 249 & 5 & 20 \\
$\quad 1991$ & & & 60 & 223 & 100 \\
Budget deficit & 0.3 & 0.1 & -3.5 & 0.3 & 8.3 \\
$\quad 1990$ & 2.1 & 3.9 & 5.7 & 1.4 & 20.0 \\
$\quad 1991$ & 1991 & 1991 & 1990 & 1991 & $\ldots$ \\
Year IMF program began & & & & & \\
\hline
\end{tabular}

Sources: For Eastern European countries, Bruno (1992, table 2). For the Soviet Union, PlanEcon Report, December 9, 1991 (nos. 43-44).

a. Data for 1991 are estimated based on the first three quarters of the year.

b. The budget deficit is expressed as a percent of GDP. All other figures are percent per year.

c. Czech and Slovak Federal Republic.

d. Data in parentheses are the change in exports as a fraction of GDP and estimate the direct impact of the decline in exports on output growth.

position of the armed forces and nuclear weapons, as well as the ownership of assets and liabilities, must be dealt with.

The 20 percent decline of output in the republics of the FSU by the end of 1991 occurred even before reform had started. A key question is whether the republics of the FSU will have to pay a further post-stabilization price similar to that of Eastern Europe-about 20 percent of output? Or, because the 1991 decline in output in both the FSU and Eastern Europe was heavily affected by the collapse of the Council for Mutual Economic Assistance (CMEA), is it more likely that most of the price has already been paid?

Other republics of the FSU generally lag behind Russia in their reform efforts (although there has been progress in some areas in some republics, such as privatization in Armenia). Because of Russia's dominance and to confine this paper to manageable proportions, I will focus on stabilization and reform in Russia. First, I will briefly describe Russia's current economic situation. Then I will review Russia's reform strategy in light of the Eastern European experience. I will then take up 
in turn questions of inter-republican trade and policy coordination and the role of external aid.

\section{The Russian Economy in the Former Soviet Union}

Russia accounts for three-quarters of the land mass and more than half the population of the former FSU. The republic is the world's largest country by size and has the world's fifth largest population. Meaningful estimates of its real GDP at the time of transition are difficult to come by or credit. Use of the black market exchange rate implies numbers-such as $\$ 150$ per capita a year-that are too low to be believable. More realistically, Abram Bergson estimates that on a purchasing power basis, per capita GDP in the Soviet Union in 1985 was somewhat below the CIA's estimate of 42 percent of the U.S. level, but well above 28 percent of the U.S. level. ${ }^{2}$ Treating the estimate as 35 percent of the U.S. level would have put Russian per capita GDP at about 38 percent of the U.S. level, in the range of such low-income European countries as Greece, Portugal, and Spain. Given the subsequent declines in output in Russia and the increases in output elsewhere, Bergson's starting point would place Russian real (purchasing power) per capita GDP in 1991 at a level similar to Mexico's.

The World Bank, which uses estimates of dollar GDP to compare countries and establish eligibility for different programs and facilities, is likely to estimate a per capita dollar GDP for Russia in the same range as Poland-about $\$ 1,800$ in 1989 -which is also at about the same level as Mexico. ${ }^{3}$

Table 2 presents data on the five most populous former Soviet republics. The Russian economy, because of its size and resources, was the least dependent of the Soviet republics on inter-republican trade; its energy resources ensured that it had a greater share of exports outside the FSU than the other republics. ${ }^{4}$ Russia is more urban and more industri-

2. Bergson (1991)

3. Joint Study (1990, p. 51) estimates the Soviet Union's 1989 per capita GDP at $\$ 1,780$, using the exchange rate that prevailed at the time, 1.8 rubles to the dollar. This number was chosen in part because it put the Soviet Union at about the same level as Poland.

4. The data may exaggerate Russia's share of exports abroad because goods from other republics tended to be marketed through Russia. 
Table 2. Basic Data for the Most Populous Republics of the Former Soviet Union ${ }^{\text {a }}$ Percent, except where indicated

\begin{tabular}{|c|c|c|c|c|c|c|}
\hline Item & Russia & Ukraine & Uzbekistan & Khazakstan & Belarus & $\begin{array}{l}\text { Soviet } \\
\text { Union }\end{array}$ \\
\hline \multicolumn{7}{|l|}{ Population } \\
\hline Millions & 148.0 & 51.8 & 20.3 & 16.7 & 10.3 & 288.6 \\
\hline Percent of total & 51.3 & 18.0 & 7.0 & 5.8 & 3.6 & 100.0 \\
\hline Percent urban & 74 & 67 & 41 & 57 & 66 & 66 \\
\hline \multicolumn{7}{|l|}{ Index of per capita } \\
\hline net output & 119 & 90 & 47 & 74 & 117 & 100 \\
\hline \multicolumn{7}{|l|}{ Index of per capita } \\
\hline income & 110 & 96 & 62 & 93 & 102 & 100 \\
\hline Infant mortality ${ }^{b}$ & 17.8 & 13.0 & 37.7 & 25.9 & 11.8 & 22.7 \\
\hline Share of net output & 61.1 & 16.2 & 3.3 & 4.3 & 4.2 & 100.0 \\
\hline Share of industrial output & 63.7 & 17.2 & 2.4 & 2.5 & 4.2 & 100.0 \\
\hline Share of agricultural output & 50.3 & 17.9 & 5.5 & 6.4 & 5.1 & 100.0 \\
\hline \multicolumn{7}{|l|}{$\begin{array}{l}\text { Exports as a percent of net } \\
\text { material product }{ }^{\mathrm{c}}\end{array}$} \\
\hline Inter-republican & 18.0 & 39.1 & 43.2 & 30.9 & 69.6 & 29.3 \\
\hline Abroad & 8.6 & 6.7 & 7.4 & 3.0 & 6.5 & 7.5 \\
\hline
\end{tabular}

Source: Joint Study (1991, vol. 1, various tables).

a. All data are for 1988, except population data, which are shown as of January 1, 1990.

b. Infant mortality is the number of deaths per thousand births.

c. In 1988, inter-1epublican exports were 21.1 percent of Soviet GDP and exports abroad were 5.4 percent of Soviet GDP. GDP data are not available at the republican level.

Table 3. Structure of Employment in the Soviet Union, the United States, and West Germany, 1988

Percent of total employment

\begin{tabular}{lccc}
\hline \multicolumn{1}{c}{ Sector } & $\begin{array}{c}\text { Soviet } \\
\text { Union }\end{array}$ & $\begin{array}{c}\text { United } \\
\text { States }\end{array}$ & $\begin{array}{c}\text { West } \\
\text { Germany }\end{array}$ \\
\hline Agriculture & 20.2 & 2.9 & 5.3 \\
Manufacturing & 23.6 & 18.5 & 32.2 \\
Construction & 9.3 & 6.6 & 6.6 \\
Wholesale and retail trade & 6.1 & 22.1 & 15.1 \\
Finance and insurance & 0.5 & 11.3 & 6.7 \\
Community services & 25.9 & 31.4 & 25.9 \\
Other & 14.4 & 7.2 & 8.2 \\
\hline
\end{tabular}

Source: Joint Study (1991, vol. 2, p. 196). Data are adjusted to ensure compatibility.

a. Data for West Germany are for 1986.

alized and has a higher per capita income than most of the other republics. Table 2 also clearly shows the lower level of economic development of the Central Asian republics, represented by Khazakstan and Uzbekistan.

The structure of employment in the Soviet Union was similar to that of other centrally planned economies. However, as table 3 shows, the 


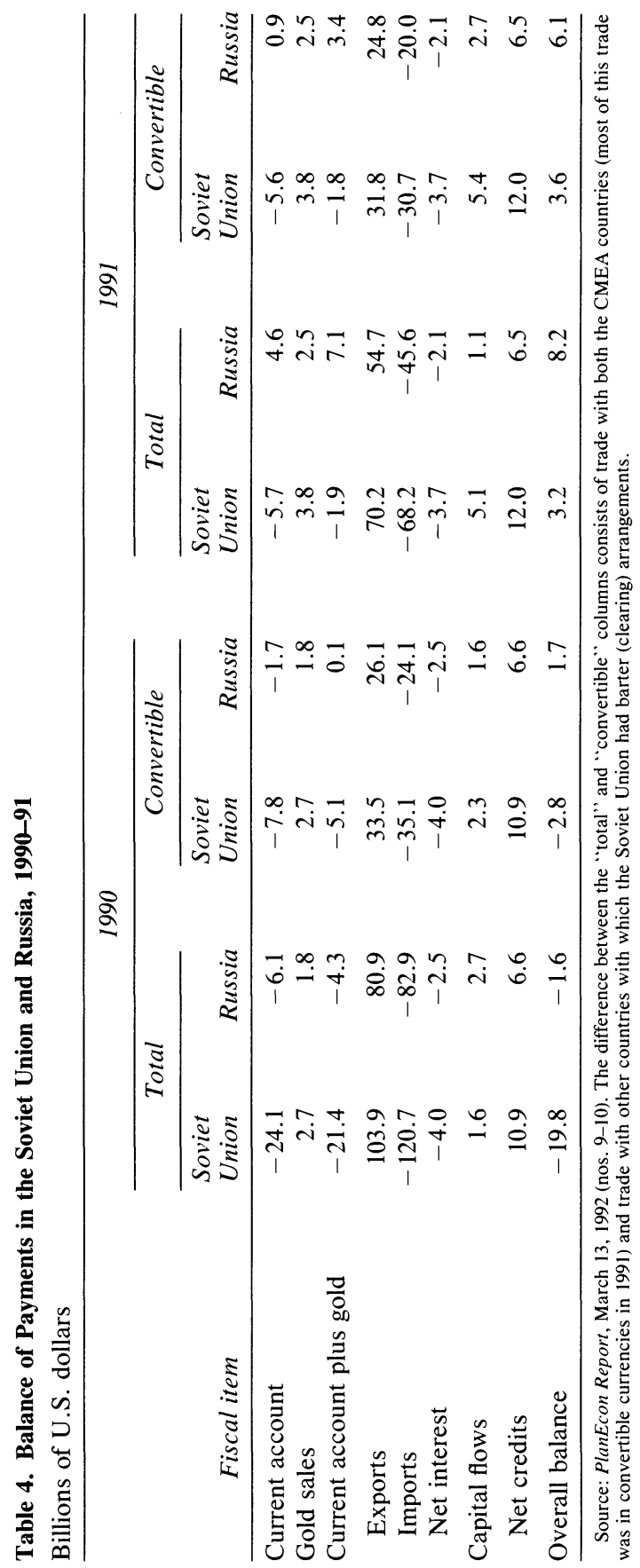


Soviet system differed from market economies especially by the small share of resources in the distribution (wholesale and retail trade) sector and in the financial sector. ${ }^{5}$ Economic transformation in Russia is certain to draw more resources into the distribution and financial sectors. It also will gradually draw workers out of the agriculture sector. Russia's share of employment in manufacturing is comparable to that in Western European countries and may not change much as economic restructuring occurs.

The domestic macroeconomic disequilibria facing the new Russian government at the end of 1991 are summarized in table 1. In the latter half of 1991, Russia took over obligations of the Soviet government, including the army payroll and the task of printing money.

Russia's balance of payments situation at the end of 1991 is difficult to appraise. Much trade with countries outside the FSU was carried out in nonconvertible currencies at artificial exchange rates and prices. Moreover, the prospects for trade with other republics after the breakup of the Soviet Union are extremely unclear. Table 4 presents the most recent data. ${ }^{6}$ These show the Soviet Union sharply reducing its current account deficit between 1990 and 1991 and Russia moving from a current account deficit to a sizable surplus between 1990 and 1991. The improvement in the current account results mainly from a greater collapse of imports from the CMEA countries than exports to them; however, imports from the countries with convertible currencies also declined sharply. During 1991, the Soviet Union received net credits larger than its balance of payments surplus.

Omitted from the trade data for Russia in table 4 are any estimates of inter-republican trade in 1990 and 1991. Russia's current account in in-

5. The same statement applies to Russia, although it is more industrialized and less agricultural than was the Soviet Union. Data comparable to those in table 3 are not available for Russia. An alternative data set, which shows industry and construction together employing 38 percent of the Soviet labor force, puts Russian employment in that sector at 42 percent. Comparable data for the agriculture/forestry sector are 19 percent for the Soviet Union and 14 percent for Russia. See Joint Study (1991, vol. 1, p. 219).

6. From PlanEcon Report, March 13, 1992 (nos. 9-10), based on data that PlanEcon describes as having been prepared by the Russian government in accordance with standard IMF methodology and the cooperation of IMF experts. However, PlanEcon warns that the data may exaggerate the strength of Russia's export performance. Note also that the share of imports and exports attributed to Russia in table 4 is constant. (I am grateful to William Nordhaus for pointing this out.) 
ter-republican trade, evaluated at actual prices, was probably in surplus in 1991; at world prices, Russia would have had a large surplus in interrepublican trade. ${ }^{7}$ However, the volume of inter-republican trade certainly declined sharply in 1991. For 1992, the questions must be at what prices inter-republican trade will be carried out, what capacity the other republic will have to pay for imports, and how much mutual credit republics can extend to one another to support trade. Inter-republican trade is likely to continue to implode.

The export and import rows in table 4 show a large decline in trade in the nonconvertible area between 1990 and $1991 .{ }^{8}$ Some of the key export and import commodities are shown in table 5. Exports of the single most important commodity-oil-declined by nearly half, a rate of decline that well exceeds the estimated percentage decline in oil production of 10 to 15 percent. ${ }^{9}$ Thus the decline in oil exports in 1991 must have resulted from both supply disruptions in the Soviet Union and demand disruptions in the former CMEA countries. Corresponding to the decline in exports (which, as noted above, was mainly in the nonconvertible area) are sharp falls in imports of machinery and raw materials (not shown), as well as consumer goods. Imports of basic foodstuffs did not drop as sharply.

In the debt agreement reached with the G-7 at the end of 1991, the Commonwealth of Independent States (CIS) governments accepted "joint and several" responsibility for the Soviet Union's debts. This obligation must be more binding on Russia than on the small republics. Russia's share of the debt (if the other republics pay their shares) is 61 percent, or just under $\$ 50$ billion. By the conventional criteria, Russia is not severely indebted. In 1991, Russian exports to the convertible currency area were $\$ 25$ billion $^{10}$ and exports to the former CMEA countries were $\$ 17$ billion. With a debt-to-exports ratio of 200 percent (this is an upper bound), the ratio for Russia for this indicator would be in the middle of

7. Joint Study (1991, vol. 1, p. 227) shows a small Russian surplus in inter-republican trade for 1987 that turns into a massive surplus when trade is evaluated at world prices. See table 8 .

8. As pointed out by Larry Summers, this shift may be exaggerated by the move of the former East Germany from the nonconvertible to the convertible area.

9. The absolute decline in production appears to have been about the same as the decline in exports.

10. PlanEcon Report, March 13, 1992 (nos. 9-10), table 20. 
Table 5. Russian Exports and Imports, 1990-91

\begin{tabular}{lrrr}
\hline \multicolumn{1}{c}{ Item } & 1990 & 1991 & $\begin{array}{c}\text { Percent } \\
\text { change }\end{array}$ \\
\hline Exports & & & \\
$\quad$ Crude oil (million barrels per day) & 2.2 & 1.1 & -50 \\
Refined oil (million barrels per day) & 1.0 & 0.9 & -11 \\
Natural gas (billion cubic meters) & 109.0 & 104.5 & -4 \\
Hard coal (million metric tons) & 35.4 & 23.9 & -32 \\
Wood (million cubic meters) & 28.0 & 19.0 & -33 \\
TV sets (millions) & 1.7 & 0.7 & -58 \\
Imports & & & \\
Equipment for food & & & \\
$\quad$ and light industry & $\ldots$ & $\ldots$. & -80 \\
Grain (million metric tons) & 30 & 136 & -7 \\
Leather shoes (million pairs) & 136 & 40 & -71 \\
Pharmaceuticals (billion rubles) & 3.1 & 1.8 & -43 \\
\hline
\end{tabular}

Source: PlanEcon Report, March 13, 1992 (nos. 9-10), p. 8.

a. Data for grain are for the first nine months only.

the range of the moderately indebted countries, as designated by the World Bank; so too would be the interest-to-exports ratio. ${ }^{11}$ The disorganization that will accompany economic restructuring will temporarily affect the economy's ability to export and increase its need for imports. However, in the medium run, Russia should be able to service its debts easily.

\section{Russia's Reform Strategy}

In formulating its economic stabilization and reform strategy, the Russian government has been able to draw on the well-known Soviet reform plans that were intensively discussed (and rejected by President Gorbachev) between 1989 and 1991, as well as analysis by Western

11. The World Bank categorizes a country's indebtedness on the basis of four criteria: debt-to-GNP ratio ( 30 to 50 percent); debt-to-exports ( 165 to 275 percent); debt serviceto-exports ( 18 to 30 percent); and interest-to-exports (12 to 20 percent). A country is severely indebted if at least three of its four debt indicators exceed the upper limit of the moderately indebted range. (See World Bank, World Debt Tables, 1991-92.) 
economists and the experience of Eastern European, Latin American, and other stabilization programs. ${ }^{12}$

The standard reform prescription is for a five-point strategy, moving as rapidly as possible on all fronts: macroeconomic stabilization, requiring both a budget that is nearly balanced and tight control over credit; liberalization of the prices of most goods; current account convertibility of the currency; privatization; and the creation of a social safety net. ${ }^{13}$ At the same time, the government should be putting in place the legal framework for a market economy.

The best known of the Soviet reform plans is the Shatalin 500-Day Plan. ${ }^{14}$ The Shatalin Plan proposed a detailed program that would have transformed the Soviet economy into a market economy within 500 days, starting on October 1, 1990: by now, the program would have been completed. The sequencing of the Shatalin Plan differs from the sequencing of plans now being implemented in Russia and Eastern Europe. The first 100 days would have been devoted to privatization and stabilization. Small businesses, housing, and vehicles would have been privatized and large companies corporatized. Revenues from privatization were expected to make a serious contribution to balancing the budget. A market infrastructure was to be put in place. Existing state orders and contracts were to run through the middle of 1991 . Wages were to be indexed. The multiple exchange rate system was to be replaced by a single rate. Imports of consumer goods were to be increased. The Soviet Union was to have cut back foreign aid.

Prices were to have been liberalized only after macroeconomic stabilization had been assured and the market infrastructure-including privatization-had been put in place. Between days 100 and 250, prices would have been liberalized, larger firms would have been privatized, and the first stage of agrarian reform would have been completed. During the next phase, lasting to day 400 , privatization would have contin-

12. In his review of Eastern European reform experiences, Bruno (1992) identifies six key issues: the extent of the initial price jump; the output decline; the fiscal balance and its sustainability; the problem of financial reform; the problem of the interim regime for socially owned enterprises; and macroeconomic policies, including the choice of the exchange rate regime and income policies.

13. See, for example, Fischer and Gelb (1991), Joint Study (1990), and Lipton and Sachs (1990).

14. The Shatalin Plan is also called Transition to Market and has been translated into English and published by the Cultural Initiative Foundation of Moscow. 
ued, antimonopoly activity would have been strengthened, and prices would have been fully liberalized. Internal ruble convertibility was to have been achieved. The plan envisaged widespread bankruptcies and saw the need for measures to support the unemployed. The last 100 days were envisaged as the beginning of the upswing.

The Shatalin group believed that a price jump at the start of a reform plan would be politically unacceptable: one reason they started with privatization was their belief that asset sales could help remove the monetary overhang. The Shatalin Plan placed much less weight on the need for early convertibility than do most Western plans. The plan also did not emphasize external assistance, believing that the Soviet Union could manage largely on its own. The plan recognized the need for greater republican autonomy and expressed concern about maintaining a single economic space. Read in the light of hindsight, the plan did not recognize the imminence of the threat of collapse of the Soviet Union. Moreover, the plan's 500-day target was unrealistically ambitious, although the notion of a sequenced program makes sense.

In any event, the Russian government started its reforms by liberalizing prices-well before it had any assurance that fiscal and monetary policy were consistent with macroeconomic stability. The normal prescription is first or simultaneously to establish macroeconomic control and then to liberalize prices. However, that prescription applies to countries where most resources are allocated through functioning markets and where price liberalization means removing incomplete price controls and reducing tariffs; this was not the situation in Russia. There, the choice was between liberalizing prices and risking hyperinflation or maintaining price controls and exacerbating shortages. In weighing its decision, the government no doubt took into account the fact that a growing proportion of transactions were being conducted in black markets, so that the effective choice to a considerable extent was between hidden and open inflation. The government must also have taken into account the unavailability of external resources to help finance the budget and stabilize the currency. Moreover, by taking a radical and virtually irreversible step, it signaled that it meant what it said about radical reform.

Obvious problems with the standard strategy derive from the difficulty of doing everything at once. The Shatalin Plan's intention to put the elements of a market system in place before liberalizing prices is 
based on the fear of perverse supply responses by managers of stateowned enterprises (more accurately, enterprises whose ownership is not well defined). But privatization before liberalizing prices is also problematic because it is impossible to value firms for sale when current prices and profits provide little guide to future performance.

I will turn now to other elements of the standard strategy, leaving aside the safety net.

\section{Macroeconomic Stabilization}

Much still must be done to secure macroeconomic stabilization in Russia. The two essentials are fiscal consolidation and a tightening of monetary and credit policy. The Russian government was able to reduce the budget deficit by more than 10 percent of GDP by cutting subsidies, defense expenditures, and investment spending. But its efforts to collect taxes have been less successful, so that a planned budget deficit of 1 percent of GDP in the first quarter of 1992 will become an actual deficit of near 10 percent.

As table 6 shows, the Soviet tax system relied primarily on profits and turnover taxes, the former collected mostly at the union level, the latter more at the republican level. On the expenditure side, subsidies-provided mostly at the republican level-took up about 20 percent of the budget and 10 percent of GDP. The Russian government, in its initial attempt at macroeconomic stabilization, cut subsidies and relied on a generalized 28 percent sales (or value-added) tax to close the budget gap. The sales tax should have been collectible through the same channels as before, and profits and export taxes also should have been paid to the Russian government. However, revenues have fallen short of projections, partly because of the decline in exports, partly because the parliament exempted food from taxation, and partly because of poor tax compliance.

In the short run, fiscal stabilization will require further spending cuts and increased revenues. The key to budget balance lies in taxing oil exports. The deficit could be closed if a planned 40 percent export tax could be collected, especially if recent declines in oil production could be reversed. Over the longer run, structural fiscal reform is needed to move away from the fiscal structure inherited from the Soviet Union. Given the inevitable weakness of tax administration at the early stages 
Table 6. Soviet Revenue and Expenditure by Government Level, 1989

Percent

\begin{tabular}{|c|c|c|c|c|}
\hline \multirow[b]{2}{*}{ Fiscal item } & \multirow[b]{2}{*}{ Total } & \multicolumn{3}{|c|}{ Distribution by government level } \\
\hline & & Union & Republican & $\overline{\text { Local }}$ \\
\hline \multicolumn{5}{|l|}{ Revenues } \\
\hline Total revenue & 100.0 & 53 & 26 & 21 \\
\hline Tax revenue & 94.6 & 53 & 27 & 20 \\
\hline Income taxes & 41.0 & 54 & 17 & 29 \\
\hline Profit taxes & 30.4 & 59 & 20 & 22 \\
\hline Personal income taxes & 10.6 & 39 & 11 & 50 \\
\hline Turnover taxes & 28.2 & 14 & 59 & 27 \\
\hline Alcohol & 10.3 & $\ldots$ & $\ldots$ & $\ldots$ \\
\hline Social insurance & 8.4 & 84 & 16 & 0 \\
\hline Taxes on foreign trade & 14.8 & 100 & $\ldots$ & $\ldots$ \\
\hline \multicolumn{5}{|l|}{ Expenditures } \\
\hline Total expenditure & 100.0 & 51 & 33 & 16 \\
\hline Economy & 41.7 & 37 & 51 & 12 \\
\hline Investment & 14.2 & 61 & 20 & 19 \\
\hline Price compensation ${ }^{\mathrm{a}}$ & 13.8 & 29 & 67 & 3 \\
\hline Procurement prices ${ }^{\mathrm{a}}$ & 6.6 & $\ldots$ & 100 & $\ldots$ \\
\hline Social and cultural & 29.0 & 26 & 37 & 37 \\
\hline Defense & 15.7 & 100 & $\ldots$ & $\ldots$ \\
\hline
\end{tabular}

Source: Joint Study (1991, vol. 1, p. 280-82). Revenues in 1989 were 393.9 billion rubles and were 41 percent of Soviet GDP. Expenditures were 480.1 billion rubles and were 50 percent of GDP.

a. Both price compensation and procurement prices are subsidy items. Most subsidies went to agriculture, primarily to support basic food prices. Cross-subsidization among firms is not recorded in the budget.

of reform, simplicity and collectibility are key criteria. ${ }^{15}$ As part of the reform, penalties for tax evasion will have to be strengthened so that Russia does not descend into the former Latin American trap where no one pays taxes, no one is punished, the budget is chronically in deficit, and inflation is perennial.

The issue of monetary or credit policy in Russia is mired in a dispute between the Central Bank of Russia and the Finance Ministry over the need for tight credit. The central bank, with the support of parliament, has argued that tightening credit now will merely lead to unemployment and bankruptcies without achieving any positive results. The Finance Ministry wants the central bank to tighten credit as part of the stabilization program.

15. Largely on these grounds, McLure (1991) argues for a consumption-based tax. See also Kopits (1991). 
Much of what happened in early 1992 was standard buck-passing. However, there are also important issues of the reform strategy. Budgetary stabilization alone cannot stop inflation if the central bank continues to expand the stock of credit by lending to the private sector. Both the quantity and cost of central bank credit matter: the Central Bank of Russia has so far been lending at a very negative real rate, which is not surprising when a price level change is occurring. However, there is no sign that the central bank is willing to move the real interest rate to a positive level even when and if inflation recedes.

The central bank has argued that it is essential not to starve existing firms of finance. The argument for generous credit at this time would start from the view that credit policy cannot be divorced from issues of enterprise reform and regional policy at this stage. Enforcement of tight credit constraints could lead to the closing of enterprises. In the current distorted price and financial systems, the wrong firms might close. Further, given the geographical concentration of industry, such closingseven if they were justified on economic grounds-could devastate the economies of entire regions, as happened, for instance, in the shipbuilding regions of the former East Germany. The standard prescription-to formulate a regional policy and finance it through the budget-is unrealistic, given the government's inability to raise revenues. The provision of cheap credit is a substitute for an articulated and financed restructuring and regional policy.

This argument is not in principle incorrect. It certainly increases the urgency of moving ahead on economic restructuring-primarily privatization-and the formulation of regional policies. However, there is no doubt that credit policy should be tightened now. Prices have been liberalized and firms need to begin to face a financial bottom line. This would encourage normal supply responses, including the disgorging of inventories-a process that would help reverse expectations of rising prices and move goods into distribution channels. The argument that a tightening of credit policies will lead to massive unemployment may become relevant within a year if no industrial restructuring takes place. However, the fact is that few firms in the reforming Eastern European countries have been closed and unemployment has increased only slowly.

In the near term, monetary policy will have to support the stabilization effort if stabilization is to succeed and to attract Western financial assistance. Several possibilities exist. First, the central bank may al- 
ready be tightening credit; there are some reports that credit growth was slow in February 1992. Second, an explicit monetary policy rule-such as a limit on domestic credit creation-or maintenance of a fixed exchange rate, could be embodied in the expected IMF agreement. Third, the interest rate may be raised to positive real levels-although this is not a sufficient policy unless accompanied by central bank refusal to roll over debts. Nonetheless, if the policy conflict continues, President Yeltsin will have to come down one way or the other on the issue.

\section{Incomes Policy}

Taxes on excess wage increases have been used in Poland. One argument for such tax-based incomes policies advanced in the 1970s is that these taxes mitigate an externality in the wage-setting process. ${ }^{16} \mathrm{~A}$ stronger argument in reforming socialist economies is that so long as the ownership of enterprises is ambiguous, firms will tend to pay out excessive amounts to workers and other stakeholders. The requirement in Poland that firms pay dividends to the government also responds to this concern, but would not by itself prevent decapitalization of the firm. An equally powerful argument derives from the potential dynamic inconsistency of anti-inflationary policy. A government committed to controlling inflation should not accommodate wage-cost pressures on prices. However, if wages do rise, the government that resists such pressures has to create unemployment, which it is loathe to do. Rather than allow itself to be put in that position, the government seeks to prevent it by taxing excess wage increases.

Opponents argue that market forces should be left to determine wages. But wage setting in government-owned firms is not a market process. As in Poland, the tax should not apply to firms in the private sector, thereby providing an incentive to privatize. It is also true that because firms can compensate workers in many ways, evasion will be widespread. Nonetheless, the balance of the argument favors the use of a tax on excess wage increases in Russia. ${ }^{17}$

16. Seidman (1978).

17. Blanchard and Layard (1991) discuss some difficulties in the implementation of the Polish excess wage tax, particularly that it allowed a period of slower-than-permitted wage increases to be followed by a catchup, in which wages could increase temporarily at more than the target inflation rate. This difficulty could be handled by rebasing the reference wage each month. (I am grateful to Olivier Blanchard for discussion of this issue.) 


\section{The Exchange Rate and Current Account Convertibility}

One attraction of currency convertibility at a fixed exchange ratethe third element in the standard package-is that there would then be a clear monetary policy rule: to conduct monetary policy so as to maintain the exchange rate. ${ }^{18}$ This would certainly help, but it would not be sufficient; as experience all over the world shows, countries can hold an exchange rate fixed for some time, even though they pursue policies that ensure it will have to be devalued at some future point. Thus, the nominal anchor of the exchange rate would have to be supplemented by a nominal anchor on, say, domestic credit, so that domestic inflation would not first erode competitiveness and then force a devaluation, as often has happened-including in Poland in 1991. ${ }^{19}$

The usual argument for a fixed exchange rate rule during stabilization is that it ensures that the supply of money will adjust automatically to relevant demand shifts at a time when shifts in the demand function are difficult to predict. ${ }^{20}$ However, this argument assumes that there are no capital controls and would not apply to the reforming formerly socialist economies. The relevant macroeconomic arguments in Russia are that the exchange rate rule is one that the central bank can understand, and that the fixed exchange rate provides direct stabilization to the price level—both because it is a highly visible price whose stability can help stabilize expectations, and because it ensures that the prices of imports will rise only at the foreign rate of inflation (changes in domestic markups aside).

Equally important is the microeconomic argument that convertibility allows the country to import the appropriate, world price system. ${ }^{21}$ Essentially, current account convertibility is the same thing as trade liber-

18. See Greene and Isard (1991) for a review of the role of convertibility in transforming socialist economies.

19. However, I am not arguing that the exchange rate should be held fixed no matter what. The exchange rate anchor is most needed in the early stages of stabilization and reform and may have to be moved to a crawling peg or other system after some time. The most important objectives of exchange rate policy must be to avoid significant overvaluation of the currency.

20. Fischer (1986).

21. Strictly speaking, this argument does not require a fixed exchange rate. However, exchange rate fluctuations would weaken the role of convertibility in helping determine domestic relative prices. 
alization. It allows individuals and enterprises to buy and sell foreign exchange freely as the counterpart to imports and exports of goods and services. Current account convertibility is not consistent with widespread quantitative restrictions on trade or foreign exchange licensing, but could be consistent with tariffs and export subsidies or taxes. In most reforming Eastern European countries, tariffs have been reduced to lower and more uniform levels than was typical in the reforming countries of Latin America. ${ }^{22}$

If the exchange rate is to be fixed, its level will matter for the subsequent course of inflation. ${ }^{23}$ Relative wages at current market exchange rates are well below levels likely to prevail if the currency stabilizes: the market is thin; most of trade is not conducted at that rate; and the rate can be moved by small amounts of foreign exchange. Setting the initial exchange rate at about the current market rate (for example, 120 rubles per dollar) would create an inflationary shock and would not provide any competition from imports. It would be preferable to set the initial rate at a level that (while allowing for some subsequent inflation) would put dollar wages in the vicinity of $\$ 50$ to $\$ 100$ per month. Whether this can be done will depend on the availability of a stabilization fund and other external financing and on the authorities' ability to prevent capital flight by exporters.

There has been much discussion of the choice between gradualism and shock treatment in Eastern European reform. The issue is in most respects irrelevant in the case of Russia. ${ }^{24}$ For countries that start with a massive macroeconomic disequilibrium, rapid stabilization is essential. So is rapid price liberalization when shortages are pervasive, as they were in Russia. Some elements of a social safety net must be put in place immediately to ensure that stabilization does not cause excessive hardship.

There are two areas in which gradualism is a viable option: trade lib-

22. Rodrik (1992) reviews Eastern European experience. He does not find much evidence for the view that foreign competition disciplines domestic price rises (which is an essential part of the view that trade liberalization helps import a price system). He attributes this result to excessive devaluations of the domestic currency.

23. Bruno (1992) suggests that Poland set too high an exchange rate at the start of its stabilization. In Israel, a slightly overvalued exchange rate was used as part of the antiinflation strategy.

24. It was more relevant to countries like Hungary and the Czech and Slovak Federal Republic that did not start with large disequilibria. 
eralization and privatization. The case for using tariffs is twofold: first, they provide protection against imports; second, they provide revenue for the budget. Both factors imply gradualism in reducing tariffs. To minimize the inevitable political pressures for special treatment, tariffs should be uniform; ${ }^{25}$ they could start as high as 30 to 40 percent and be reduced over five years to low levels. That way, they would provide protection for domestic producers while the economy is reorganizing; generate revenue for the budget while a more sophisticated tax system is being set up; and still allow a foreign price system to be imported. The fiscal case for trade taxes is already accepted in Russia on the export side, where oil exports will be taxed. The case is also strong on the import side. While tariffs carry potential political economy dangers, so does a lack of budget revenue. Gradual tariff reductions can be built into programs with the international agencies.

\section{Enterprise Reform and Privatization}

Soviet industrial enterprises were very large and industry was correspondingly monopolized. ${ }^{26}$ See table 7 for a comparison of industrial concentration in the Soviet Union, the United States, and Poland. In 1988, 47,000 industrial enterprises operated in the Soviet Union. In the first half of 1990, enterprises owned by local authorities and republics accounted for 35 percent of value added. ${ }^{27}$ The private sector in the Soviet Union was minuscule. Nearly 90 percent of employment was in state enterprises, 8 percent was on collective farms, and less than 4 percent was in private activity (including cooperatives). The number of cooperatives surged at the end of the Soviet period, exceeding 250,000 (with nearly 40 percent in construction) in the middle of 1991, employing more than 6 million people and accounting for as much as 5 percent of GDP. How-

25. There is a theoretical case for reducing all tariffs proportionately, such that the ratio of domestic-to-foreign prices approaches unity gradually. I assume that such tariffs are too liable to manipulation to be a useful baseline.

26. Joint Study (1991, vol. 2, p. 40) lists products for which industrial concentration by producer is high. They include sewing machines ( 100 percent of output is produced by a single enterprise); hydraulic turbines (100 percent), steam turbines ( 95 percent) (with hydraulic and steam turbines being produced by the same company); freezers (100 percent); and many more.

27. Data are from Joint Study (1991, vol. 2, pp. 15-40), which provides a succinct description of the enterprise sector and reform strategies. 
Table 7. Size Distribution of Employment in Industrial Enterprises in the Soviet Union, the United States, and Poland

Percentage of all workers

\begin{tabular}{lrccc}
\hline & \multicolumn{4}{c}{ Number of employees } \\
\cline { 2 - 5 } Country and year & $1-99$ & $100-499$ & $500-999$ & $\begin{array}{c}\text { 1,000 } \\
\text { and over }\end{array}$ \\
\hline Soviet Union (1988) & 1.8 & 13.2 & 11.7 & 73.3 \\
United States (1985) & 27.6 & 33.8 & 12.7 & 25.8 \\
Poland (1986) & 10 & 25 & 15 & 51 \\
\hline
\end{tabular}

Source: Data for the Soviet Union are from Joint Study (1991, vol. 2, p. 37). Data for the United States (for the manufacturing sector) are from Statistical Abstract of the United States, 1988, p. 499. Data for Poland (for the socialized sector, only) are from Lipton and Sachs (1990, p. 84).

a. In 1988, 15.6 percent of the Soviet industrial workforce was employed in enterprises with between 5,000 and 10,000 workers, and 21.5 percent was in enterprises that employed more than 10,000 workers.

ever, 80 percent of these cooperatives were operating within existing enterprises $^{28}$ - a process that can be viewed either as the beginning of industrial restructuring through the spinning off of viable components of firms or simply as the ripping off of state assets.

In the debate over shock treatment versus gradualism, the pace of privatization and the development of the private sector are relevant issues that pit experts on China $^{29}$ against those involved in Eastern European reform. China's gradualist reforms, which started in agriculture, have not involved formal privatization and state firms have not been sold to private individuals. Nonetheless, a vibrant, essentially private, sector has developed in Chinese agriculture and industry and the reforms have been extremely successful by any economic measure.

In Eastern Europe, the stated preference has been for rapid privatization. In practice, Eastern European progress in privatization has been disappointing, especially in Poland, where sophisticated schemes for mass privatization have yet to be implemented. ${ }^{30}$ Success has been considerable in small-scale privatization - the privatization of small (primarily retail) firms, whose purchase or lease is often financed by the governmental agency making the sale. Privatization of medium- and largescale firms has been less successful, although the Czechoslovak voucher scheme could soon result in privatizing much of industry-and perhaps

28. Johnson and Kroll (1991).

29. See, for example, Singh (1991) and McMillan and Naughton (1992).

30. Berg (1992). 
shortly thereafter could also bring widespread disillusionment with the promises of financial operators. Hungary, which has avoided grandiose schemes and encourages current management and workers to pursue the sale of their firms subject to approval by the State Property Agency, appears to be making some progress with privatization of larger firms. ${ }^{31}$

The circumstances in Russia, where the state and the state order system have collapsed, are different from those in China. The Russian government has been losing control over the enterprise sector and must clarify the ownership status of firms and the rules under which they are to operate, for the old rules no longer apply. In that sense, gradualism in the reform of the enterprise sector in Russia cannot occur. The new rules and the new strategy must be developed and implemented so that firms can again begin to operate with clear management objectives. ${ }^{32}$ The government also should aim to move firms out of state control as soon as possible.

However, enterprise reform needs to be gradualist in recognizing that privatization of large firms will take time-perhaps up to a decade-until most of the largest firms have been mostly privatized. Gradualism also is needed to implement a strategy in which the state will be responsible for a significant, but diminishing, part of industry for years and not for months.

Such a strategy would look much like those being carried out in practice (although not in rhetoric) in Eastern Europe and the approach that is starting in Russia. The first Russian auctions of small firms took place at the beginning of April 1992, but local authorities are not showing much enthusiasm about the sales. ${ }^{33}$ Small-scale privatization is both urgent-as a precedent and signal that the privatization effort is seriousand important, because the distribution sector in which such firms operate is vastly underdeveloped in Russia. ${ }^{34}$ Growth in this area is likely eventually to come from new firms, but opening up the sector requires

31. Fischer (1991b).

32. In the New Economic Policy (NEP) in the 1920s, large firms, which were kept under state ownership, were told to behave like commercial enterprises. They formed themselves into large trusts and presumably maximized profits like good monopolists should.

33. Shleifer and Vishny (1992).

34. Much of the success of the NEP in the 1920s resulted from permitted private enterprise into the distribution sector. Private firms' activities brought the sector that predominated at the time-the rural sector-actively back into the economy. See Fischer (1992). 
the privatization of existing firms owned by local authorities. As emphasized by Andrei Shleifer and Robert Vishny, existing stakeholders will have to be given incentives to obtain their support for privatization. ${ }^{35}$ If rapid progress cannot be made in this easiest area of privatization, the entire privatization and reform process will be severely set back.

Stories about spontaneous or nomenklatura privatization of larger firms abound. Case study evidence presented by Simon Johnson and Heidi Kroll suggests that firms' managers have generally strengthened their control and their residual property rights during the period since 1988 , but that they have not obtained de jure ownership of firms. ${ }^{36} \mathrm{John}-$ son and Kroll emphasize the part played by management and downplay the role of the nomenklatura. Newspaper and other reports of corruption in the transfer of property tend to emphasize the role of the bureaucracy. It is not inconsistent with Johnson and Kroll's evidence to argue that in many cities and regions, property rights are being (insecurely) passed from the state sector to others, to the benefit of the nomenklatura.

Both existing management and existing workers will have to support privatizations of larger firms if firms are to be moved quickly into the private sector. Thus privatization schemes that give existing workers and management significant shares of the privatized firm are more likely to succeed than those that ignore the current distribution of implicit property rights. ${ }^{37}$ Shleifer and Vishny suggest that the shares be given in a way that directly encourages management and workers to privatize; for instance, shareowners could receive dividends only after privatization.

The first step in privatization of larger firms-and one that can come within months-should be corporatization: moving the firms out of bureaucratic control and into the control of corporate boards. Workers will have to be represented on these boards. Inevitably the board's composition will have to compromise between the need for knowledgeable members and the need to keep out the nomenklatura. For the largest firms, it would be desirable to bring in Western experts, but they should speak Russian.

35. Shleifer and Vishny (1992).

36. Johnson and Kroll (1991).

37. Shleifer and Vishny (1992). 
As in Hungary, Russia from the beginning should be encouraging privatization by existing firms, subject to state approval. This process can take place at any time while other privatization schemes are being developed and implemented.

A possible privatization strategy following corporatization starts with each board-for manageability, say, boards of firms with more than 2,500 employees-presenting a restructuring plan to the privatization agency. All firms whose boards present a plausible restructuring scheme that does not involve large externalities for a given region or city will go into a privatization pool. Ownership rights for the firms in the privatization pool should be distributed to citizens, as well as workers and managers, through a voucher scheme-perhaps one that gives individuals ownership in holding companies, rather than individual firms. Smaller firms could be privatized through vouchers in the same or a separate scheme. The Eastern European evidence is that such schemes can get stuck, which is all the more reason for urgency.

It will be necessary during the restructuring process for the state to decide how to deal with existing financial assets and liabilities in firm balance sheets. There is a real attraction in a widespread write-down or even write-off of debts and corresponding assets, an action that would have to involve the banks. The banks could be compensated by being given claims on a diversified portfolio of firm equity and by being given government bonds as reserve assets.

The large size of the enterprises and the concentration of industries creates both advantages and problems for boards considering restructuring. On the benefit side, the large firms are too vertically integrated; each provides its own complete range of ancillary services, such as catering, haircutting, and manufacturing spare parts in machine tool shops. Restructuring can begin by peeling off viable parts of firms. Similarly, because the firms are in many cases monopolies that hold most of the country's technical knowledge to produce that commodity, it is likely that some part of the firms will survive in the new regime.

The prime disadvantage of largeness is that rapidly closing down a giant firm that dominates the economy of a city or region will not be politically possible. Such giant firms will not go into the privatization pool; for them Russia will have to develop regional and restructuring policies. To state the point clearly, this arrangement borders on industrial policy. But there is no point in pretending that the Russian government will be 
able to do what most other governments-most obviously the German government-cannot, which is to leave such restructurings to the market, particularly because the market for corporate restructuring does not yet exist. ${ }^{38}$ To put the point succinctly, privatization is not an adequate restructuring policy. Pretending that restructuring will take place if left to the market only delays doing what has to be done. An agency, operated with external financial and expert support, should be set up to deal with those firms that do not go into the privatization pool, to develop restructuring plans (and, if necessary, phased steps to shut down firms).

Within a few years, the Russian private sector will grow more through the creation of new firms than through privatization. Thus an essential element of the enterprise reform strategy consists of developing the legal, financial, and educational systems and infrastructure to support new enterprises.

Eastern European governments have been concerned that at the current over-devalued exchange rates, foreigners could buy up too much of their countries at too low a price. A similar concern seems to have arisen in the FSU in the recently completed negotiations over a Chevron investment in the Tengiz oil field, which revealed a Groucho Marx-like fear on the former Soviet side of accepting any deal to which the other side agreed. Despite such concerns, foreign direct investment, which brings not only finance but also management expertise and technology, should be and is being welcomed by the Russian government. Russia has hired foreign advisers to help develop and appraise potential foreign investments; this is an area in which international agencies such as the World Bank, which presumably can operate more as honest brokers, might play an active role. At present, the real problems with foreign investment are that there is too little rather than too much of it, and that much of that is going into deals that are often corrupt. While foreign investors are obviously extremely interested in Russia, foreign direct investment will not flow on a substantial scale, such as the scale on which it is now flowing to Hungary (where it is more than 3 percent of GNP), until some sense of stability returns.

Of course, foreign expertise can be obtained without foreign investment. There is no reason why foreign management should not be imported on contract, even if foreign firms do not want to invest directly.

38. On the active role of the Treuhandanstalt in managing the industrial transition in East Germany, see Carlin and Mayer (1992). 
THE FINANCIAL SECTOR. The creation of a viable private sector depends on the availability of financing both to purchase existing firms and to create new firms. To some extent, financing for privatization can come from the state sector-for example, in small-scale privatization, by leasing rather than immediately selling firms-and by setting the prices of firms low enough, through voucher schemes. The development of new firms depends more on the development of the banking system, through restructuring of existing balance sheets and the creation of new banks or units within existing banks. The possibility of canceling existing debts between firms and banks and replacing them with bank claims on a diversified range of firms has already been noted. Implicit or explicit state guarantees would be needed to ensure that banks do not go under if firms fail on a large scale.

Financial sector reforms have lagged in Eastern Europe, except in Hungary. Many new and specialized banks have been set up in Russia, but the existing banks have not yet been reformed.

THE AGRICULTURAL SECTOR. Attention in privatization focuses on industrial enterprises. However, improving the agricultural sector is one of the highest reform priorities. Improvements in the availability and quality of food would not only benefit the population, but also bring strong political support to the reform process. Thus the priority being put on agricultural reform by outside agencies providing technical assistance is well-directed. ${ }^{39}$ It appears that many farmers on collectives do not want privatization; however, there must be many farmers who do. The development of private ownership of land and the extension of private agriculture are areas in which rapid progress is possible and would have a high payoff. ${ }^{40}$

There is one other area where privatization could have a high payoff but has generally been implemented slowly in other countries: housing.

\section{New Currencies, Inter-republican Trade, and Economic Coordination}

The dissolution of the Soviet Union will lead to a decline-at least in the near term-of inter-republican trade and the introduction of inde-

39. The World Bank is coordinating a major study of reform of the agricultural sector.

40. For a preliminary view of reform priorities in agriculture, see Joint Study (1991, vol. 3, chapter V.5). 
pendent currencies in some republics of the FSU. At present, the fifteen republics of the FSU continue to use one currency and have agreed in principle to allow the free passage of goods among them. But the Baltics and Ukraine have already announced that they intend to introduce their own currencies and other republics are preparing to do so. Ukraine's coupons are close to being a new currency. Moreover, goods are not flowing freely among republics.

Would the republics be better off staying in the ruble zone or introducing their own currencies? If Russia continues to move ahead on price liberalization, stabilization, and convertibility, there would be advantages for the other republics to staying in the ruble zone and automatically acquiring a more stable and convertible currency. In addition, inter-republican trade would probably hold up better if the ruble zone were maintained..$^{41}$ Offsetting these advantages is the certainty that there will have to be major changes in relative wages among republics; these would be easier to attain if exchange rates among the republics' currencies could be adjusted. Republics with less developed tax systems may want to use seigniorage more than others; this too requires an independent currency. Of course, operating an independent currency would require improving the quality of central bank management.

By virtue of its size and relative wealth, Russia would be less affected by the breakdown of inter-republican trade and the ruble area than the other republics. At the first stage of its reform program, Russia was able to force price liberalization on the others because they were not prepared to introduce their own currencies and manage their own economies. Russia's progress in achieving macroeconomic stabilization has put pressure on other republics by reducing the availability of rubles to cover their budget deficits and meet payrolls. Russia hopes to tighten fiscal and monetary policies and move toward convertibility within a few months. The other republics will either have to stabilize at the same time or introduce independent currencies. Beyond this defensive motive, some republics view an independent currency as a necessary attribute of sovereignty.

In any case, Ukraine and perhaps the Baltics are planning to introduce their own currencies later this year; other western republics are

41. This argument is not analytically clear-cut. If a country had an independent currency and was trying to maintain free trade, it would have one more instrument with which to attain its free trade goal-exchange rate changes. However, more often, countries introduce trade restrictions to protect the value of the currency. 
likely to follow. Presumably these republics would want their currencies to be convertible as soon as possible, but because reforms have been slow, convertibility will be delayed. The Central Asian republics will probably want to stay in the ruble area as long as they continue to receive transfers from Russia. Those transfers could be made explicitly through budgetary transfers or trade credits or by pricing Russian exports at internal Russian prices (that is, net of export taxes). For 1992, Russia will not levy export taxes on oil sent to other republics. Thus at least temporarily, Russia is seeking to maintain the wider trading zone. In the longer run, Russia's decision on whether to provide transfers must be mainly political.

New currencies can be introduced cooperatively by retiring an equivalent volume of rubles held within the territory or owned by citizens of the republic and replacing them with the new currency. A more confrontational approach would be to ignore the existing stock of rubles, leaving citizens to dispose of them as best they can. There is a mutual interest in avoiding a confrontation on this issue, so that new currencies are likely to be introduced cooperatively.

Republics other than Russia lag in the reform effort, not only because they are not yet committed to moving toward a market system, but also because they lack the qualified personnel needed to manage a reform program. Even Ukraine, which is politically committed to genuine independence and therefore has to develop an independent economic policy management ability, is only now beginning to pull an economic team together-and Ukraine has a large population, financial resources, and diaspora on which to draw. Economic management will be a real problem for other republics, even with the assistance of the international agencies.

\section{Inter-republican Trade}

The breakup of the ruble zone would speed the decline of inter-republican trade, especially if currencies are not convertible. It is often said that the republics of the FSU were extremely closely integrated, more than market economies are likely to be. Table 2 includes some data on the extent of trade, showing Belarus's exports at 70 percent of net material product (NMP). Because table 2 presents data for the largest republics, it understates the importance of trade for the representative repub- 
Table 8. Inter-republican and Foreign Trade Balances of Selected Republics, 1987

Percent of net material product

\begin{tabular}{lrrrrrrr}
\hline & \multicolumn{3}{c}{ At domestic prices } & & \multicolumn{3}{c}{ At world prices } \\
\cline { 2 - 4 } \cline { 6 - 8 } Republic & Inter-republican & Abroad & Total & & Inter-republican & Abroad & Total \\
\hline Russia & 0.9 & -8.3 & -7.4 & & 7.4 & 3.3 & 10.7 \\
Ukraine & 1.6 & -7.7 & -6.2 & & -3.9 & -1.5 & -5.4 \\
Uzbekistan & -20.6 & -0.5 & -21.1 & & -23.6 & 0.5 & -23.1 \\
Khazakstan & -20.0 & -7.8 & -27.8 & & -24.4 & -4.1 & -28.5 \\
Belarus & 11.8 & -7.6 & 4.2 & & -8.3 & -0.8 & -9.5 \\
Lithuania & -4.5 & -7.9 & -12.3 & & -37.0 & -2.2 & -39.2 \\
\hline
\end{tabular}

Source: Joint Study (1991, vol. 1, pp. 226-7).

lic. The average 1988 export ratio (exports/NMP) in inter-republican trade for the other ten republics was 57 percent. For the Soviet Union, the GDP/NMP ratio was 1.34, so the average inter-republican export/ GDP ratio for the smaller republics would be 40 to 45 percent. ${ }^{42}$ This is about the same as the dependence of the smaller European economies on intra-European trade. But because of the extreme specialization of production in the FSU, the republics must be more mutually dependent for vital production inputs than they will be after economic reform.

The massive changes in relative prices that have to occur will disrupt production all over the FSU. They also will impose huge adverse balance of payments shocks on many of the republics, particularly the energy importers. Table 8 presents estimates of the balance of payments shift caused by moving to world prices for the five largest republics and for Lithuania, one of the worst hit former republics. ${ }^{43}$ These impacts are being cushioned by Russia's agreement to maintain a relatively low price of oil (compared to world prices) for inter-republican trade for 1992. Nonetheless, the data indicate the macroeconomic adjustments that must be made over the next few years.

The republics appear to be moving toward a series of bilateral trade deals for 1992. These agreements would avert the worst outcome-a complete collapse of trade along with the Soviet Union. However, the

42. Joint Study (1991, vol. 1, p. 225). I assume in making this calculation that the services that are responsible for the gap between NMP and GDP are not traded.

43. Similar data are presented in PlanEcon Report, March 13, 1992 (nos. 9-10). 
danger remains of a sharp reduction of the volume of trade as bilateral balancing-requiring the double coincidence of wants-replaces the multilateral trade that took place in the FSU. In a simple calculation, using a matrix of inter-republican trade, I assumed that with bilateral clearing, trade between each pair of countries would settle at the lower level of imports or exports in 1988. The volume of trade would decline to 44 percent of its previous value under this constraint, a huge shock with potentially dangerously disruptive effects on trade.

There is no question that trade patterns within the FSU have to change drastically over the next few years. It is thus tempting to argue that whatever decline in trade takes place is part of a process of creative destruction that will lead more rapidly to an efficient pattern of output. This is wrong in two respects. As a matter of theory, trade that must ultimately disappear may nonetheless be desirable in a second-best situation. As a matter of political economy, a very rapid decline in production-even production that must ultimately disappear-may stop a reform program in its tracks. The recent experience of Eastern Europe provides suggestive evidence that trade-related shocks can produce a too rapid decline in output.

\section{The Inter-republican Payments Mechanism}

What can the republics do to mitigate and smooth these shocks? They have much to gain by collaborating on questions of trade and macroeconomic reform-on matters of inter-republican payments and, if necessary, in the introduction of new currencies. At present, the republics lack a framework of collaboration. The case for the introduction of a mechanism like the European Payments Union (EPU) has been made by Rudiger Dornbusch and Daniel Gros, among others. ${ }^{44}$ The case for a payments mechanism includes: the need for a collaborative framework; the potential gains from multilateral, rather than bilateral, clearing of trade; and the fear that without such a mechanism, trade could spiral downward as each republic imposes restrictions on other republics that they fear cannot pay. The case against introducing a new mechanism views a payments union as a mechanism that will maintain central plan-

44. Dornbusch (1992); Gros (1991). 
ning of trade and impose quantitative restrictions, rather than promote rapid convertibility - a charge given some plausibility by the fact that current account convertibility was attained in Western Europe only in 1958.

Much of the controversy over a payments union and the apparent Russian opposition to it stem from the emphasis on the EPU precedent. The EPU board did play a major role in managing trade and payments among its members, in many respects taking the place of the IMF. ${ }^{45}$ That is not needed in the FSU, where the IMF and the World Bank already are active, nor is the necessary experience available in the FSU. Rather, the need is for a more modest organization, the Inter-republican Payments Mechanism (IRPM). This group would have three tasks: to operate as a technical organization to clear payments; to provide a mechanism to extend credit among republics, and to economize on reserves; and to provide a convenient focus for broader inter-republican cooperation.

The issue is usually posed as convertibility versus a payments union. But components of an IRPM would be needed even with convertibility. The banking systems in the republics of the FSU are underdeveloped and explicit arrangements for inter-republican payments will need to be worked out, with the help of outside agencies. The arrangements would involve relations among the central banks of the republics, as well as among the nascent private banking systems. This is the first necessary function of an IRPM. Second, credit could be extended among the republics to try to prevent credit constraints from, in effect, imposing bilateral balancing on trade. The central banks of the republics will have to agree on mutual credit limits, to be administered through the IRPM. As in the case of the EPU, increasingly onerous settlement provisions will have to be imposed as imbalances increase, and upper bounds should be set on imbalances. Convertibility is not a full substitute for such arrangements because the republics will be short of reserves. An IRPM can be viewed as a means of economizing on hard-currency reserves, setting up an alternative means of financing temporary imbalances among the republics, even after convertibility is attained.

The IRPM should be thought of as a source of transactions balances

45. Kaplan and Schleiminger (1989). 
to finance current transactions, not as a source of long-term financing. Given the adjustments some republics must make, they will run current account deficits for some years. Financing plans for those deficits will involve agreement with the IMF and may include separate intergovernmental agreements among republics for the extension of longer-term credit. Those agreements could be negotiated at IRPM meetings, but they are not an inherent part of an IRPM.

Some framework for continuing inter-republican collaboration and economic relations is clearly needed. The republics need to collaborate not only in developing payments mechanisms and providing the associated credits, but also to prevent potentially destructive trade and currency reforms. To this point, they have been collaborating on an ad hoc basis, including negotiating bilateral trade agreements. A more permanent multilateral arrangement, in the context of the IRPM, possibly with external technical assistance, would be constructive. It is not inherent in the creation of an IRPM that it would slow progress to a market system; the inclusion of international agencies would help ensure that it moves in the right direction.

There is one other potential role for an IRPM. It could be seen as a mechanism through which external assistance could be funneled to the republics and conditionality for such assistance could be imposed. There might be a case for using IRPM in this way if the republics were not members of the IMF and the World Bank. Because they are members, bilateral assistance can be provided through cofinancing of IMF and Bank programs, with conditionality agreed upon in direct negotiations among the agencies and the republics. The need for donor coordination remains. ${ }^{46}$

In the area of inter-republican coordination and payments, as in privatization, the best is the enemy of the good, and the transition has to be managed. The "best" in this case would be full convertibility, with adequate reserves, for all currencies in the FSU. The current structure of inter-republican trade must be destroyed. But convertibility with adequate reserves will not happen anytime soon, and trade can be destroyed too rapidly if nothing is developing in its place. These difficulties make the case for an IRPM that goes beyond the necessary minimum of a technical organization to manage the payments mechanism. 


\section{External Assistance for Russia}

Maintaining the pace and direction of political and economic reforms in the FSU is certainly in the interests of the West. The West has recognized this interest by engaging the FSU through diplomacy, through defense arrangements, and with financial assistance and membership in the international organizations. In April 1992, the G-7 announced a \$24 billion aid package for Russia, for 1992. Because aid remains controversial and the full details of the aid package are not yet clear, I will discuss the general case for financial assistance for Russia and the other republics.

For economic and political stability, the reforming republics need four types of assistance: humanitarian, technical, and general financial aid, as well as access to Western markets. Humanitarian and food aid is reaching the FSU. So is technical assistance, particularly as the international agencies, including the European Community, have moved decisively into the area. The technical assistance is so far concentrated on Russia, but is beginning to spread to the other republics, where it is needed even more. However, technical assistance from official agencies is usually provided in the visiting fireman form: in assisting the newly forming governments, it is important to station people in the republics for periods of a year or more, if possible. While technical assistance is now flowing, the FSU can easily and productively absorb more.

It is almost impossible to get accurate data on aggregate assistance that so far has been provided to the Soviet Union and the other republics of the FSU. Table 9 presents one set of data on total financial assistance commitments to the Soviet Union and the republics in the period between September 1990 and December 1991. The total committed in those 16 months-more than $\$ 67$ billion-is impressive; so are the facts that more than half that amount was committed by Germany, and so little was provided by the United States and Japan.

Unfortunately, table 9 is severely misleading. Least important, it is slightly misleading in categorizing food aid. Agricultural credits, the form of U.S. aid, are classified as export credits. The category of food aid in table 9 is probably aid provided by the donors in the form of food, rather than, say, credits. The more serious difficulty is that the table presents aid commitments over some future horizon, some of them in the 
Table 9. Aid Committed to the Former Soviet Union, by Donor, September 1990-December 1991

Billions of U.S. dollars ${ }^{a}$

\begin{tabular}{lccccc}
\hline & $\begin{array}{c}\text { Food and } \\
\text { medical } \\
\text { assistance }\end{array}$ & $\begin{array}{c}\text { Technical } \\
\text { assistance }\end{array}$ & $\begin{array}{c}\text { Exports and } \\
\text { other credits }\end{array}$ & $\begin{array}{c}\text { Troop } \\
\text { withdrawal } \\
\text { aid }\end{array}$ & $\begin{array}{c}\text { Total } \\
\text { assistance }\end{array}$ \\
\hline Europe & 1.3 & 1.6 & 32.4 & 10.4 & 50.5 \\
$\quad$ Germany & 0.7 & 0.2 & 20.4 & 10.4 & 34.7 \\
Italy & $\ldots$ & $\ldots$ & 4.0 & $\ldots$ & 5.8 \\
United States & $\ldots$ & $\ldots$ & 4.1 & $\ldots$ & 4.1 \\
Japan & $\ldots$ & 0.2 & 2.5 & $\ldots$ & 2.7 \\
South Korea & $\ldots$ & $\ldots$ & 3.1 & $\ldots$ & 3.1 \\
Total $^{\mathrm{b}}$ & 1.4 & 1.8 & 45.1 & 10.4 & 67.6 \\
\hline
\end{tabular}

Source: International Economic Insights, January-February 1992, p. 48. Figures based on unofficial data compiled by the European Community.

a. Data in source were in European currency units (ecu). An exchange rate of $\$ 1.25 / \mathrm{ecu}$ was used.

b. Rows and columns do not sum to totals because of omitted entries.

form of ceilings on export credit agency exposure, some of which were withdrawn following the collapse of the Soviet Union, and some of which may represent debt outstanding rather than potential flows. The data do not represent aid disbursements. The republics could not access these amounts of finance within a year or even within several years. The more useful aggregate measure of Western assistance in 1991 appears in table 4- $\$ 12$ billion in net credits. Russia's share of this sum is estimated at $\$ 6.5$ billion. Even in this lower figure, the official credits were to a considerable extent replacing disappearing bank credits.

The package of financial assistance for Russia announced in April 1992 has two components. The first is a currency stabilization fund of $\$ 6$ billion. The second is balance of payments support of $\$ 18$ billion, including $\$ 2.5$ billion of debt rescheduling. The currency stabilization fund is to come entirely from the IMF's General Arrangements to Borrow; about $\$ 4.5$ billion of the remaining financing is expected to come from the international agencies; and $\$ 11$ billion represents bilateral financial assistance, largely export credits, some of it already committed. The currency stabilization fund is intended to support the convertibility of the ruble, presumably at a fixed exchange rate. This step should be taken only when and if the Russian government tightens the budget and monetary policy. That could be before the end of 1992 . 
The balance of payments support must have been calculated on a needs basis, reflecting the amount of import financing Russia will need if some modest level of recovery in output—or at least only a small further decline-is to take place this year. In fact, the continuing disruption of inter-republican trade makes further deep declines in output this year very likely. This means (to answer a question raised at the beginning of the paper) that Russia and the other republics are likely to suffer far worse recessions than Eastern Europe is now experiencing.

Opposition to the provision of financial assistance to Russia is based on several arguments. First, the type of advice and conditionality that accompanies IMF and World Bank assistance is generally wrong; for instance, it urges gradualism when shock treatment is needed. ${ }^{47}$ Second, the money will be wasted because corruption is rife. After all, critics ask, what has happened to the $\$ 67$ billion of assistance already provided? Third, the money would be better spent elsewhere, for instance, in Africa. Fourth, easing of the financial constraint on the Russian (or any) government allows it to put off doing the right thing. In the Russian context, that would be to generate as much foreign exchange as possible by selling oil leases and other assets that the West wants. Fifth, we cannot afford it.

Some of these arguments are valid and should find their reflection in IMF and Bank conditionality-for instance in developing oil leases, in requiring budgetary and credit tightening, and in other reform measures that are part of Russian agreements with the agencies. The argument about Africa is unfortunately wrong; the money would not be spent there either. Careful monitoring of IMF, World Bank, and other programs should prevent these particular funds from being misused; nonetheless the aid donors should be pushing hard on the corruption issue. However, there should be no illusion that the West provided $\$ 67$ billion of assistance to the FSU last year. Rather, as noted above, the total was closer to $\$ 12$ billion and some of that was used to repay debts to the West. The arguments about whether we can afford such assistance are too familiar to stand repetition.

The argument that governments perform best when left on their own is wrong. The correct argument is that programs forced on countries by the international financial institutions tend not to work. Programs that 
are chosen by governments, to which the government is fully committed, do tend to work well with external assistance. Despite claims to the contrary, the countries that reformed successfully during the 1980 s reformed with external support. The programs were their own, but the reformers were not left to their own devices.

The issue in Russia is momentous. Russia will not always be weak and this is the time when the basis of a new relationship is being set. If the promised assistance materializes and works, Russia will need substantial aid for only a few years because Russia's balance of payments is fundamentally strong.

Of course, the aid must be conditional on economic policies. That is why the IMF and World Bank are involved. That is also why even bilateral assistance should be conditioned upon an agreed-upon reform program (most simply through co-financing of Fund and Bank programs). Similarly, the other republics should receive aid only when they pursue reformist policies. So far, they have been reforming very slowly.

\section{The Need for a Long-Term Strategy}

The drama of economic reform comes at the beginning, with political change, new governments, IMF agreements, convertibility, debates about the role and inadequacy of aid, and the rest of the scene that is increasingly familiar from Eastern Europe and the FSU. This initial phase is crucial, exciting, and interesting. The issues are clear-cut andthanks in large part to the policymakers and advisers involved in the early stabilizations-the necessary policies are reasonably well understood.

Another crucial part comes later, when growth is not yet visible, when the industrial structure has not changed, and when early promises have not been fulfilled. This is what has happened in Poland, two years after the start of the reform. In Russia, the government has not overpromised, but its reform program also will face severe political difficulties in a few years if structural policies are not addressed as intensively now as stabilization and financial assistance.

The Shatalin Plan was right to set out a complete, phased restructuring plan, although wrong in its timing. What long-term restructuring policies should be pursued now so that they come on line in the next few 
years? The most important is the reform of the enterprise sector, through privatization, the development of the distribution sector, and industrial restructuring, as discussed above. Other sectors that deserve special attention in Russia are the energy sector (a potent source of foreign exchange), the agricultural sector, and the financial sector. The foreign private sector has a potentially important role to play in all these sectors.

Government action would be useful in one other area. Infrastructure is crumbling in Russia, as it is in the rest of Eastern Europe. Infrastructure investment complements private investment and private investment will take some time to develop. Now is the time for governments to begin upgrading infrastructure, if necessary, with external assistance, for instance from the World Bank. Such investments do not always need public funding. Telecommunications investment is taking place in Eastern Europe with private external financing. Transportation infrastructure can also be developed with the assistance of private capital. With a little imagination, so can other parts of infrastructure. As government gets out of areas in which it does not belong, it should move into areas where it does belong. Upgrading infrastructure early in the program makes eminent sense as part of a growth-oriented reform strategy. 


\section{Comments and Discussion}

Lawrence Summers: Stanley Fischer's thorough paper does an excellent job of articulating what might be labeled the "economists' consensus" view of the situation in the former Soviet Union (FSU). Despite economists' reputation for never being able to agree on anything, a striking degree of unanimity exists in the advice that has been provided to the nations of Eastern Europe and the FSU. The legions of economists who have descended on the formerly communist economies have provided advice very similar to, if less nuanced than, the advice provided in this paper.

The consensus view of the transition problem articulated by Fischer consists of five propositions:

1. The situation in formerly communist economies is unlike anything that the world has ever encountered before.

2. Simply addressing stabilization is insufficient to solve this problem because it is profoundly structural in nature.

3 . The multitude of problems faced by formerly communist economies are all connected. Examples abound of newly privatized enterprises subtracting value by buying oil at a nickel a gallon, or of privatization attempts foundering because of the difficulty of valuing enterprises when oil is selling for a nickel a barrel.

4. The three "ations"- privatization, stabilization, and liberalization-all must be completed as soon as possible. Maintaining the momentum of reform is a crucial political problem. An adequate set of transfer programs to support the unemployed is essential, as is a safety net for other losers in the reform process.

5. Western support cannot hurt the prospects for reform and has a prospect of helping, both politically and economically. Given the enor- 
mous worldwide stake in the countries of the FSU making a successful transition to a democratic market system, more assistance is better than less.

I suspect that these statements would find agreement with most economists who have thought about the FSU. And the propositions are consistent with the position that the IMF and World Bank are taking as they negotiate with the nations of Eastern Europe and the FSU. So I have little to quarrel with in Fischer's paper. I merely want to comment in a little more detail on several of the issues that he takes up. Many of my comments are amplifications, rather than qualifications or criticisms, of Fischer's analysis.

First, there is a real issue as to whether reform in the FSU is being adequately financed. According to the Fischer paper (similar estimates are available elsewhere), imports into Russia in 1990 were $\$ 82.9$ billion; in 1991 , they were only $\$ 45.6$ billion. While the exact use to which the vaunted $\$ 24$ billion aid package would be put is not clear, it is clear that it will not be nearly large enough to offset the dramatic import compression that the Russians are now suffering. It is unlikely that imports will rise to even two-thirds of their historic level in the next few years, even if the entire scheduled aid package were disbursed. The situation is considerably bleaker in the fourteen non-Russian republics.

It is instructive to compare the situations of the FSU and Eastern Europe. The nations of the FSU surely face far greater problems. They are further from the West geographically, systemically, and in terms of past contacts. The FSU economy is far more distorted in both a financial and real sense than were any of the communist economies of Eastern Europe, and it is facing the challenges of dissolution. Yet import compression in the FSU-even without taking account of the breakdown of internal trade-is likely to be several times as serious as import compression in Poland and other parts of Eastern Europe.

Second, at what level should the exchange rate be pegged? Thinking only of Russia, Fischer suggests that the exchange rate be pegged in such a way that when average wages are converted into dollars, they come out to about $\$ 100$ a month. At current exchange rates, wages are in the $\$ 10$ to $\$ 20$ range, so Fischer's figure implies a very substantial real appreciation. I suspect it is unrealistic to expect or to try and contrive a real appreciation of such a large magnitude. 
For all the reasons I mentioned as to why Russia is in more dire straits than Poland, I believe that there is a case for setting the wage at a lower dollar level in Russia than in Poland (where the monthly figure was close to $\$ 75$ following stabilization). Considerations beyond the low productivity of Russian enterprise point in this direction, including protection of enterprises that need protection, and the fiscal consequences of oil export taxes, which are more favorable at a lower, rather than a higher, exchange rate (a consideration that is not present in Poland). On balance, I suspect that $\$ 50$ a month is a more plausible short-run target than $\$ 100$ a month. Of course, any kind of fixed exchange rate is not a viable option until some control over macroeconomic fundamentals is achieved.

Third, the energy sector should be a crucial locus of reform. The potential gains in export revenues from increasing the efficiency of petroleum production and increasing efficiency in energy use probably exceed $\$ 100$ billion by the end of the 1990s. Right now, energy intensity per unit of GNP is more than five times the corresponding figure in Europe, and easy repairs could raise drilling and shipping productivity substantially. Investments in the energy sector are probably the most levered investments that the West can make to raise the flow of hard currency to the FSU.

Russia and several other republics have potentially valuable oil properties. I am reminded of the statistic that in 1983, the value of Mexico's oil reserves was 20 times the value of Mexico's outstanding debt, yet Mexico had a debt crisis. I wonder whether some part of financial engineering with respect to the FSU could involve arranging for the transfer of hard currency to Russia and other republics with petroleum resources, in return for claims on their oil reserves-perhaps claims guaranteed in some way by the Western governments that are seeking to help the FSU.

Fourth, I think Fischer devotes too little attention to the issue of what to do about the Gordian knot of the financial sector. The banks' principal assets are loans to the state sector. Because most of the enterprises are under water, the banks are, as well. It is pointless to fix up the banks if the enterprises are still in trouble. And without viable banks, enterprise restructuring and liquidation is difficult to arrange. It is tempting to say that the right answer is to leave existing institutions aside and set up new banks to loan to new enterprises. That is happening on a large scale right 
now. The problem is that the current arrangement is mostly Ponzi finance, with less lending to new enterprises than to bankers' brothers-inlaw. Supervision surely must be improved. But given the magnitude of the supervision failures in the countries of the OECD, it would be unrealistic to rely on supervision as the complete solution to financial sector problems.

Fifth, it seems to me that Fischer is entirely correct in emphasizing the problems with the Polish model of non-enterprise reform, which is to pound your fist on the table and insist upon privatization or nothing. But listening to Fischer's description of what should be done leaves one understanding why that advice is given in Poland. The prospect is not encouraging for the Russian government organizing to have a board that would assess the proposed restructuring plans enterprise-by-enterprise, perhaps in conjunction with the banks to which the enterprise is in debt. The confusion engendered by efforts to handle Canary Wharf in the West points up the difficulty.

In addition to underscoring the importance of privatization, I would emphasize the need for mass corporatization. This is highly desirable because of the importance of giving incumbent workers and managers in current firms a claim that will ultimately be sold. This provides an incentive to maximize enterprise value, even in advance of privatization.

Sixth, Fischer makes light of a very important part of the Russian balance of payments projection-the projection of substantial balance of payments improvement from raising prices on sales to other republics. Two separate problems arise here. There is a real problem of the large subsidies that Russia has been giving to the other republics by selling commodities, principally oil, at very low prices. This is not a problem that any amount of payments mechanism could circumvent, but a real structural difficulty; by accepting it in making arrangements with Russia, one raises the aid requirement or, alternatively, reduces the prospects for the remaining republics.

Seventh, there is the question of whether a payments union or some similar institution should be set up when and if republics introduce their own currencies. Here I think it is important to distinguish between the payments mechanism and the extension of credit. I believe that there is a clear case for multilateral clearing that will conserve on what will inevitably be scarce hard currency reserves. There is a much weaker case for the extension of long-term credits from one republic to another, or from 
the West to some kind of inter-republican payments mechanism. There is Fischer's point that the IMF is probably better at performing some of the tasks that the European payments mechanism did than any Russian bureaucracy likely would be any time soon. And there is the additional point that the republics with the least responsible macroeconomic policies will have the largest trade deficits and will, therefore, have the greatest access to finance. So for the West to finance its support for the republics through such a mechanism would be to give up important opportunities to apply conditionality based on the pursuit of specific policies at the republic level.

Eighth, I wonder whether Fischer does not somewhat overstate the case for infrastructure investments. It is hard to deny that infrastructure investment is good; likewise, it is hard to say that having a good infrastructure is not important, and there is much that is wrong with the infrastructure in the FSU. But I doubt that it is too bad, relative to the infrastructure in other equally poor countries. The available aid flows are trivial relative to the cost of modernizing the infrastructure of the FSU. It may well be that support for consumption to maintain the political momentum for reform is actually a higher priority than support for new infrastructure investment.

William Nordhaus: In reading Stanley Fischer's analysis of the issues of economic reform in Russia and the former Soviet Union (FSU), I found myself admiring the work of a master chef. Fischer has analyzed all the necessary data ingredients for economic reform, combined them using the classical macroeconomic recipes, and produced a three-star set of recommendations for the sous-chefs who are in charge of the kitchens in Moscow, Kiev, and Washington.

Yet there is something vaguely disturbing about the underlying premises of the Fischer paper. The issue arises in the very first paragraph, where Fischer writes:

Less than four months after the Soviet Union was dissolved, Russia had decisively liberalized most prices and was on the road to macroeconomic stabilization and convertibility of the ruble.

Fischer is one of the great chefs of our age-the Escoffier of stabilization plans-but I think his conclusion is surely premature. I cannot help think of another Fisher-Irving-who opined on the state of the U.S. economy in February 1930 and concluded that "the threat to business 
due to the dislocation of purchasing power by reason of transfers of stock holdings will be temporary. . . . For the immediate future, at least, the outlook is bright." 1

I think the issue can be posed as the struggle between the cookbook (or duck) view and the chess view of the world. What is the difference between master chefs and chess grandmasters? Making a great duck à l'orange is basically a routine activity. It involves getting a fine duckling, a few navel oranges and other easily obtained ingredients, and possessing the skill to make its rich, meaty duck-essence sauce. By routinely and scrupulously following the cookbook or the skills learned from one's master, one can succeed day in and day out.

By contrast, playing a great game of chess is the essence of a nonroutine activity. Although each game starts exactly the same way, and even a few standard opening gambits exist, the game rapidly evolves into a historically unprecedented configuration. After a few moves, each game becomes unique. This means that, while general strategies are possible, no routine or cookbook approach to chess exists. Like chaotic systems, chess games become increasingly divergent from one another as they evolve.

The question for the Fischer paper is whether economic stabilization policies are more like the routine exercises of preparing a duck à l'orange or like the chaotic experience of playing a chess game. A strong tendency to hold the duck view of the world exists in bureaucracies or international organizations, such as the IMF or the World Bank. These two international financial institutions have perhaps 100 supplicants asking for aid and must respond in a principled and formulaic fashion to requests. This bureaucratic imperative is reinforced by a deep-seated human need to simplify and classify so as to try to bring order to the confused and chaotic jumble of data. For economic stabilization purposes, the IMF therefore brings the reigning orthodoxy to bear on a given crisis.

From this, we have the canonical five-plan for stabilization that Fischer describes, and this would apply everywhere from Azerbaijan to Zaire. Fischer states that the "output price" of a stabilization plan is 20 percent. This leads him to wonder whether, since Russia's output has 
already declined around 20 percent, Russia must pay another 20 percent. Today's stabilization plans sound chillingly like a modern version of blood-letting: no pain, no gain.

The question this raises is whether the duck à la Bank view of stabilization policies is appropriate for all stabilization purposes independent of economic, social, and political initial conditions. Or is it possible that in a country that had devoted 70 years to systematically destroying every shrub and sprout of private market activity, the strategy might need to be different? Are the former-socialist economies so different that trying orthodox methods will simply fail? (Let me say that I do not disagree with Fischer's view of the world. At the same time, if an options markets existed, I would place a lot of money in deep out-of-the-money puts against the duck à la Bank view of the world.)

With these general reservations, let me highlight some of the reasons why I think that the Russian situation is more complicated than the duck à la Bank view of the world tends to suggest.

To begin with, it is clear that the Russian government has followed the IMF cookbook faithfully. Prices have been liberalized and free entry into virtually every area exists. This is the only major country in the world that has no duties on imports. It is always reassuring to see that textbook propositions in economics are borne out: there definitely are goods on the shelves as a result of the price decontrol.

The prognosis for most of the other ingredients of the duck à la Bank would seem to be in much greater trouble. The Russian economic reformers seem to hold to the Chicago variant of the duck school, which holds that private economic activity will quickly spring up when state regulations are withdrawn. Yet, plans for privatizing are moving oh-soslowly. The first step to privatization is usually thought to be "corporatization," which involves separating state-owned enterprises from the government in corporate form with their own management and boards of directors. This step has been postponed until September 1992. At the same time, old habits die hard: the privatization minister, Anatolii Chubais, has given orders to the regional privatization agencies and has threatened to dismiss their heads if they "fail to meet their targets."

External convertibility of the ruble seems a long way off, given the current level of the exchange rate. As of April 1992, the exchange rate was somewhere between 80 rubles and 140 rubles to the dollar, depending upon which ruble we are considering (more on this later). 
Fischer recommends that the Russians defend an exchange rate of 10 rubles to the dollar. That is going to require some pretty heavy paper.

At an exchange rate of 100 rubles per dollar, the first-quarter wage rate was $\$ 10$ per month. At this rate, Russia ties Ethiopia as the world's second poorest country. The undervalued exchange rate results in such absurdities in the price system as gasoline selling at 4 cents a gallon, bread selling at 3 cents a loaf, and subways costing 0.5 cent a ride, along with restaurant meals that cost Russians several months' salary and a total Russian GNP less than Hong Kong's (at current exchange rates).

Aside from these intriguing details, the sobering thought is that the foreign-exchange market is so far from what would seem to anyone a sensible equilibrium. This market is relatively well developed by Russian standards, has low transportation costs, and involves a standardized and divisible commodity. If this market is so far from a sensible equilibrium, what can we expect for oil, steel, spare parts, and housing?

One reason why stabilization is not a simple case of duck à la Bank is that economic reforms in the FSU must at the same time manage the monetary and fiscal system, as well as the external indebtedness of a crumbling empire. Fischer discusses some of the issues involved in the potential breakdown of inter-republican trade in an enlightening way, but I will focus on what seems to be the key one-the monetary system.

Even as a unitary government before August 1991, the Soviet Union had no way of conducting monetary policy with respect to household spending, although it could in principle use credit controls for enterprises. The breakup of the Soviet Union has led to a proliferation of monies in the ruble zone.

Many analyses today overlook the fact that the internal inconvertibility of the ruble is increasing. Today, there is nominally one money in the FSU, the ruble; however, de facto the number of different forms of money is nineteen and counting. The multiple currencies arise because the different rubles are in fact incompletely convertible into one another. There is the one paper ruble ("cash money"), which circulates everywhere in the FSU. In addition, there are ruble accounts ("noncash money") of enterprises in the banking systems of each of the fifteen republics. In the West, we call this electronic money, but in the FSU, it seems more apt to call these "abacus rubles." These ruble accounts, however, do not appear to be convertible into abacus rubles across republican boundaries and have different values on exchanges. The seven- 
teenth money is the Ukrainian coupon; the eighteenth is hard currencies such as the dollar. Moreover, there are frozen hard-currency accounts since the Vneshekonombank (the bank of foreign economic relations) ran out of hard currencies in December.

At present, the Ukrainian coupon (which looks like a low-grade piece of engraved currency) seems to be trading at par with the paper ruble, but in Russia at least, the abacus ruble appears to be selling at a discount of about 40 percent relative to the paper ruble. Belarus is reported to be introducing a coupon; Estonia is reported to have contracted with Canada to print an Estonian crown; and other republics are presumably on either the coupon or currency track. This suggests that sixteen paper currencies will exist along with the sixteen to thirty abacus currencies in the near future, assuming that none of the autonomous republics, autonomous oblasts, autonomous okrugs, or cities introduce its own ration coupons.

What are the options? The first, which seems to be the cookbook IMF approach, is to push the republics to sit down, reason together, and run a common monetary policy in a ruble zone. This approach in essence is recommending that fifteen republics, full of mutual distrust and lacking in central-banking competence, accomplish in a few months what Europe has been unable to do in several years. This is theoretically sensible but practically impossible.

The second approach would be for the republics to admit the inevitable fact and begin to develop their own individual monetary and fiscal policies, along with some form of convertibility or clearinghouse mechanism to facilitate trade.

In the current situation, I believe that the second approach-of independent republics with independent currencies and monetary and fiscal policies-eventually will emerge. The sooner this approach is recognized, the sooner this region will emerge from monetary chaos. However, what is obvious from an economic point of view runs into deep political and practical objections. Now that the evil empire has turned into the kinder and gentler empire, it makes life simpler for outsiders to have the empire stay together; the tendency for Westerners to keep sending superglue to the FSU is what we might call the Gorbachev fallacy. A single political entity provides one-stop shopping for diplomats, economizes on IMF and World Bank stabilization funds, and most importantly, slows the proliferation of nuclear weapons. I'm told, in addition, that the cuisine in Dushanbe is pretty dismal. 
In the presence of the disintegrating monetary system, it is not surprising that production has fallen and that trade has fallen even more sharply. One of the striking findings in Fischer's paper is that from 1990 to 1991, trade with the former ruble trading zone collapsed. Fischer's table 4 shows that trade with the ruble bloc fell by about half in 1991, whereas trade with the convertible zone fell only slightly. This result suggests that the risks of a similar collapse within the FSU are extremely serious if the ruble becomes internally inconvertible.

Russian officials estimate that output has fallen between 10 to 20 percent this year. There is no sign of private production of goods (whereas the growth of retail trade in flea markets is booming, but fantastically inefficient).

The real danger would appear to be an exacerbation of the problem of bottleneck production declines. A telling example is the breakdown of buses in Moscow. Apparently, one-third of the buses are not operating because of a shortage of spare parts. The buses are Hungarian-built. After the Russians insisted on hard-currency payments for oil, the Hungarians insisted on hard-currency payments for spare parts. However, the Russians ran out of hard currency last winter, so there is nothing to pay the Hungarians for spare parts; hence, no operational buses.

The worrisome thought is that the Hungarian bus syndrome will spread in the month ahead, particularly if the monetary crisis becomes worse, the republican currencies become increasingly inconvertible, and inter-republican trade breaks down. In a recent survey of 62 Moscow firms, 88 percent reported that "the lack of raw materials, semi-finished goods, [and] equipment" were among "the most serious obstacles for the growth of production at your enterprise for the last half year." Only 2 percent of firms reported that "insufficient demand for your production" was the most serious obstacle. ${ }^{2}$

I know of no economic cookbook that tells us how to handle monetary management in a crumbling empire. The disintegration of the Austrian empire led to the replacement of the Austro-Hungarian monetary system with a number of national currencies. This produced substantial inflation in most and hyperinflation in some, even though monetary management was under the supervision of the Reparations Committee set

2. The Russian Economic Barometer, 1992, Moscow (January), pp. 11, 16. I am indebted to Joe Peck for this reference. 
up under the Treaty of Versailles. ${ }^{3}$ Fischer suggests setting up an interrepublican payments system under the benevolent directorship of the international agencies-an excellent idea if it can be engineered.

It is difficult to predict the future evolution of the FSU monetary system, but my rubles are on the scenario that the proliferation of monies will continue until effective national (that is, republican) currencies are established. A happy outcome would be the slow establishment of stable currencies and external convertibility such as occurred after World War II in Western Europe. But we are surely a long way from that.

What might a nightmare scenario be? As things get worse, we might see growing trade barriers among republics, basically because republics refuse to sell their goods for the abacus rubles of other republics. Monetary trade would then gradually turn to hard currencies, as in the case of the Hungarian bus parts. At going exchange rates, dollarization is an expensive operation.

Given the scarcity of hard currency, inter-republican trade might then gradually degenerate into barter. This process would be hardest for the small republics like the Baltics, which are most nationalistic, have few hard-currency exports, and depend heavily on imported goods and services. However, the descent to barter poses perils even for Russia because of the highly specialized structure of the FSU economy and because the collapse of the economies of its trading partners will boomerang upon itself. (Even a healthy market economy like Finland has suffered a major downturn because of the collapse of its southeastern trading partners.)

The nightmare scenario is that the descent into barter would gradually lead to a breakdown in vital production links; the difficulties would move from the nuisance of spare parts for buses to indispensable inputs for nuclear power plants, oil and gas production, railroads and other transportation links, and medical supplies. Such wide-scale barter is unprecedented in the modern world; even the wildest hyperinflations did not manage to drive the affected economies back to widespread barter. It is hard to see how the tender sprouts of democracy and civil society could survive a breakdown of the productive process such as would occur in the descent to barter.

What should the youthful team of Russian economists and their Western advisers do? I have no basic disagreements with Fischer's recipes.

3. Keynes (1920). 
I worry that they have not been proven in the laboratory of the former centrally planned economies, but they seem to be the best bet.

The problem is that they represent only the first moves in the chess game. They do not address the next moves in the game: how to reinvigorate production when the state has withdrawn, how to prevent pauperization when the hoards run down, how to introduce a spirit of enterprise where it has been rooted out, or how to extract money from the West when it gets bored and the stabilization fund is used up.

What should be the next steps? There are two points that run counter to the duck à la Bank view. First, I think we have to face up to the likelihood that, aside from the simplest economic activities, it will take much longer for private markets to spring up to replace the state sector. Russia needs an industrial policy to cope with the collapse of production in key industries like food, energy, transportation, and exports.

Second, I believe that the major republics should quickly move to introduce independent monies so that they can run their own monetary and fiscal policies. Each republic should strive at least to have internal convertibility between currency and deposits. This will require substantial technical assistance from the West, but the expertise is available.

The move toward fiscal and monetary separation and the introduction of industrial policies will solve none of the issues about how to increase oil production or achieve convertibility of the fifteen or so currencies; however, it may at least prevent the decline into the Stone Age of barter that is currently under way. Any chef that can produce that outcome deserves four stars.

\section{General Discussion}

Participants generally agreed that issues of macro-stabilization are better understood than micro issues, such as privatization and price liberalization. Michael Bruno noted that a range of micro problems have beset the transitions in most Eastern Europe economies. However, the problems are even worse in the former Soviet Union because of conflicts among the republics on issues as fundamental as internal payments arrangements. Robert Hall stressed the need to reform the financial system, emphasizing that a central problem was the moral hazard associated with the government controlling the creation of money. To avoid the problem, Hall suggested that the republics create local monetary 
units tied to an outside currency such as the deutsche mark, with the Bundesbank controlling the money supply and remitting seigniorage to the republics. Such an arrangement would solve the problems of convertibility and payments arrangements that are otherwise so intractable for a primitive economy. Hall suggested that other important micro objectives should include developing institutions outside the monetary system to intermediate between lenders and borrowers, and developing the systems of property rights, contract enforcement, and dispute settlements that a free enterprise system requires. Richard Cooper responded that an initiative is already underway involving Russian-speaking U.S. lawyers who are working in Russia to develop such a legal system.

Several panelists discussed the difficulties of convertibility raised in William Nordhaus' comments. Cooper observed that, apart from blocked enterprise funds, which were never intended to be used generally, household currency deposits are essentially convertible into cash. With foreign exchange markets now free, Russians already could convert their rubles into dollars. However, Rudiger Dornbusch noted that, because no adequate bank clearing system exists, such convertibility is possible only in the form of cash, which greatly limits its usefulness. He offered this as one possible explanation for why traders have not done away with the "Hungarian bus syndrome" that Nordhaus described. Stanley Fischer acknowledged the practical difficulties that limit functional convertibility, even though legal convertibility now exists.

Lewis Alexander suggested that, because most republics are now trying to join the IMF, the obligations of IMF membership, as codified in the articles of agreement, could provide a framework for negotiating reforms in the monetary system of those republics. He suggested that an historical precedent for this existed in the 1920s, in the role played by the reparations commissions that managed the currency separation that followed the break-up of the Austro-Hungarian empire. Dornbusch, however, warned that the IMF would not have the power to force needed changes in the FSU and had no experience mediating between countries such as Russia and Ukraine. He reasoned that solutions to the basic problems required political change and compromise. Thus rather than relying on the IMF to influence policy in the FSU, the industrial nations should arrange for a broadly respected political figure, such as Helmut Schmidt, to represent their concerns with the highest level of political decisionmakers in the republics of the FSU. 


\section{References}

Berg, Andrew. 1992. "The Logistics of Privatization in Poland." Paper prepared for NBER conference on Transition in Eastern Europe (February 2629).

$\rightarrow$ Bergson, Abram. 1991. "The USSR Before the Fall: How Poor and Why." Journal of Economic Perspectives 5 (Fall): 29-44.

Blanchard, Olivier Jean, and Richard Layard. 1991. "Post-Stabilization Inflation in Poland.' Unpublished paper, Massachusetts Institute of Technology and London School of Economics (May).

Bruno, Michael. 1992. "Stabilization and Reform in Eastern Europe: A Preliminary Evaluation." Unpublished paper, International Monetary Fund (March).

Carlin, Wendy, and Colin Mayer. 1992. “The Treuhandanstalt: Privatization by State and Market." Paper prepared for NBER conference on Transition in Eastern Europe (February 26-29).

Dornbusch, Rudiger. 1992. "A Payments Mechanism for the Commonwealth and Eastern Europe.' Unpublished paper, Massachusetts Institute of Technology (January).

Eberstadt, Nicholas N. 1991. "How Not to Aid Eastern Europe." Commentary 92 (November): $24-30$.

Fischer, Stanley. 1986. "Exchange Rate versus Money Targets in Disinflation." In Indexing, Inflation, and Economic Policy, by Stanley Fischer. Cambridge, Mass.: MIT Press.

. 1991a. "Economic Reform in the USS and the Role of Aid." BPEA, 2:1991, 289-301.

- 1991b. "Privatization in East European Transformation," Working Paper 3703. Cambridge, Mass.: National Bureau of Economic Research (May).

- 1992. "Russia and the Soviet Union Then and Now." Paper prepared for NBER conference on Transition in Eastern Europe (February 26-29).

$\rightarrow$ Fischer, Stanley, and Alan Gelb. 1991. "The Process of Socialist Economic Transformation." Journal of Economic Perspectives 5 (Fall): 91-105.

Fisher, Irving Norton. 1956. My Father, Irving Fisher. New York: Comet Press Books.

Greene, Joshua E., and Peter Isard. 1991. "Currency Convertibility and the Transformation of Centrally Planned Economies." Occasional Paper 81. Washington: International Monetary Fund (June).

Gros, Daniel. 1991. “A Soviet Payments Union?' Unpublished paper, Centre for European Policy Studies (November).

Johnson, Simon, and Heidi Kroll. 1991. "Managerial Strategies for Spontaneous Privatization."' Soviet Economy 7: 281-316.

Joint Study. 1990. The Economy of the USSR: A Study Undertaken in Response to a Request by the Houston Summit: Summary and Recommendations, by 
the International Monetary Fund, the World Bank, the Organisation for Economic Cooperation and Development, and the European Bank for Reconstruction and Development. Washington: World Bank.

Joint Study. 1991. A Study of the Soviet Economy, 3 vols., by the International Monetary Fund, the World Bank, the Organisation for Economic Cooperation and Development, and the European Bank for Reconstruction and Development. Paris: Organisation for Economic Cooperation and Development.

Kaplan, Jacob J., and Gunther Schleiminger. 1989. The European Payments Union: Financial Diplomacy in the 1950s. Oxford: Clarendon Press.

Keynes, John Maynard. 1920. The Economic Consequences of the Peace. New York: Harcourt, Brace, and Howe.

Kopits, George. 1991. "Fiscal Reforms in the European Economies in Transition." In The Transition to a Market Economy, edited by Paul Marer and Salvatore Zecchini. Paris: Organisation for Economic Cooperation and Development.

Lipton, David, and Jeffrey Sachs. 1990. "Creating a Market Economy in Eastern Europe: The Case of Poland.' BPEA, 1:1990, 75-133.

McLure, Charles E., Jr. 1991. "A Consumption-Based Direct Tax for Countries in Transition from Socialism.' Working Paper WPS 751. Washington: World Bank (August).

McMillan, John, and Barry Naughton. 1992. "How to Reform a Planned Economy: Lessons from China." Oxford Review of Economic Policy (forthcoming).

Rodrik, Dani. 1992. "Foreign Trade in Eastern Europe's Transition: Early Results." Paper prepared for NBER conference on Transition in Eastern Europe (February 26-29).

Seidman, Laurence S. 1978. “Tax-Based Incomes Policies." BPEA, 2:1978, 301-48.

Shleifer, Andrei, and Robert W. Vishny. 1992. "Privatization in Russia: First Steps.' Paper prepared for NBER conference on Transition in Eastern Europe (February 26-29).

Singh, Inderjit. 1991. "Is There Schizophrenia about Socialist Reform Theory?" Transition (Socialist Economic Reform Unit, World Bank) 2(July-August):1-4. 